\title{
Analysis Of Disability And Stigma On Self-Concept On Leprosy Patients
}

\author{
Srinalesti Mahanani*, Desi Natalia Trijayanti Idris \\ STIKES RS. Baptis Kediri, Indonesia \\ *nalesti.mahanani@gmail.com
}

\begin{abstract}
If leprosy is not handled carefully, it can cause disabilities and conditions become an obstacle for leprosy patients in living their social life. The existence of disabilities in lepers causes physical changes to the sufferers. The changes in leprosy sufferers can become stressors that affect self-concept. The purpose of this study was to determine the effect of disability and stigma on self-concept in leprosy patients. The research design used was correlation analysis with cross sectional data collection. The population was all leprosy patients in the outpatient installation of the Daha Husada General Hospital with a total sample of 50 respondents who were selected using the purposive sampling technique. Measurement of disability is developed from the standard provisions of the Ministry of Health of the Republic of Indonesia. Stigma measurement uses the Internalized Stigma of Mental Illnes Scale (ISMI) which was developed by The International Federation of Anti-Leprosy Associations (ILEP) in 2011. Meanwhile, the Self-Concept instrument is developed from indicators according to theory. The analysis used was logistic regression starting with the examination of the variables and the results were $\mathrm{p}$ value $=0.40$ for disability and $\mathrm{p}$ value $=0.49$ for stigma. It can be interpreted that disability gives potential 5,652 times and stigma gives potential 6,205 times for self-concept.
\end{abstract}

Keywords : Leprosy, Disability, Stigma, Self-Concept 


\section{STRADA Jurnal Ilmiah Kesehatan}

DOI: $10.30994 /$ sjik.v9i2.410

ISSN: 2252-3847 (print); 2614-350X (online)

Vol.9 No.2 November 2020 Page.926-935

\section{BACKGROUND}

According to Kunoli leprosy is a chronic disease caused by bacteria that attack the skin and peripheral nerves. ${ }^{1}$ The cause of leprosy is the bacteria Mycobacterium Leprae. Leprosy can be cured, but if not treated it can cause permanent disability. If leprosy is not handled carefully, it can cause disability, and conditions become an obstacle for leprosy patients in living a social life to meet their socioeconomic needs. ${ }^{2}$

East Java is in the first rank and becomes $30 \%$ of the main contributor to leprosy sufferers nationally, while for the City of Kediri itself in 2014 the number of active lepers was 237 people, while in 2015 to October 2015 there were 241 people. Data at the Kediri Leprosy Hospital, in 2015, showed as many as 4,862 patients with 151 new cases and 4,711 old visits. Data from the medical records of the Daha Husada Kediri General Hospital of patients with leprosy in the outpatient installation which routinely control during the month September-November 2018 reached 143 people. Based on the results of pre-research conducted by Sipahoetar (2020) at the Daha Husada General Hospital, Kediri City, it was found that 17 leprosy patients had disabilities due to leprosy, with details of 2 respondents (10\%) experiencing disabilities in the eyes, a total of 5 respondents $(25 \%)$ had disabilities in their hands and a total of 10 respondents $(50 \%)$ had disabilities in their legs ${ }^{3}$

Leprosy can actually be prevented by early diagnosis and regular and accurate treatment with Multi Drug Therapy (MDT). The principle of preventing defects and their aggravation is basically checking the eyes, hands and feet regularly; protect the eyes, hands and feet from physical trauma and take care of themselves. ${ }^{4}$ Long leprosy sufferers will show leprosy reactions with nerve pain, weakness, multiple skin lesions, eye pain, or signs of systemic disease due to bacterial infiltration. attacking the respiratory mucosa, bones, and testes. If leprosy is left untreated, it can cause damage to skin tissue (skin, upper respiratory mucosal, finger and face bones) and nerve damage (causing loss of sedation / weakness of the muscles supplied by the affected nerve).

If leprosy is not handled carefully, it can cause disabilities and conditions become a barrier for leprosy patients in living their social life. ${ }^{5}$ According to Dhelya leprosy causes complications, namely leprosy reactions, prevention of disability (POD), protein interactions in damage caused by leprosy, and nerve damage in leprosy. ${ }^{6}$ This will also cause leprosy patients to experience decreased productivity, self-criticism, a pessimistic outlook on life, negative feelings towards themselves, and withdrawal. The existence of disabilities in lepers causes physical changes to the sufferers. The changes in leprosy sufferers can become stressors that affect self-concept. ${ }^{7}$

The potential for self-concept disorder in leprosy sufferers is the reason that nurses need to identify self-concept in lepers. Disorders of self-concept that are not identified will result in behavioral changes in people with leprosy. Wiwiek suggests that one of the reactions of clients and families to changes in self-concept depends on the support available. The need for nurses and families to accompany leprosy patients in fostering leprosy patient confidence so as to increase a positive self-concept and reduce complications from leprosy. The purpose of this study was to determine the effect of disability and stigma on self-concept in leprosy patients. ${ }^{7}$

\section{METHODS}

Based on the research objectives, the research design used was correlation analysis with cross sectional data collection. The population was all leprosy patients in the outpatient installation of the Daha Husada General Hospital with a total sample of 50 respondents who were selected using the purposive sampling technique. The independent variable in 


\section{STRADA Jurnal Ilmiah Kesehatan}

DOI: $10.30994 /$ sjik.v9i2.410

ISSN: 2252-3847 (print); 2614-350X (online)

Vol.9 No.2 November 2020 Page.926-935

this study is disability and stigma, while the dependent variable is self-concept. The instrument used in this study was a questionnaire. Measurement of disability is developed from the standard provisions of the Ministry of Health of the Republic of Indonesia. Stigma measurement uses the Internalized Stigma of Mental Illnes Scale (ISMI) which was developed by The International Federation of Anti-Leprosy Associations (ILEP) in 2011. Meanwhile, the Self-Concept instrument is developed from indicators according to theory. The analysis used is the frequency distribution, bivariate correlational test between independent and dependent variables and then multivariate test for the two independent variables on the dependent variable using logistic regression.

\section{RESULT}

Results of Measurement Levels of Disability, Stigma and Self-Concept in Leprosy Patients Table 1. Categories of Disability Levels in Leprosy Patients at Daha Husada Hospital,

Kediri City in August $2020(\mathrm{n}=50)$.

\begin{tabular}{ccc}
\hline Disability Levels & f & \% \\
\hline 0 & 3 & 6,0 \\
\hline 1 & 35 & 70,0 \\
\hline 2 & 12 & 24,0 \\
\hline Total & 50 & 100,0 \\
\hline
\end{tabular}

Table 2. Categories of Stigma in Leprosy Patients at Daha Husada Hospital, Kediri City in August $2020(\mathrm{n}=50)$.

\begin{tabular}{ccc}
\hline Stigma & $\mathbf{f}$ & $\mathbf{\%}$ \\
\hline Heaviness & 0 & 0,0 \\
\hline Moderate & 11 & 22,0 \\
\hline Medium & 36 & 72,0 \\
\hline Mild & 3 & 6,0 \\
\hline Total & 50 & 100,0
\end{tabular}

Table 2. Categories of Self-Concept in Leprosy Patients at Daha Husada Hospital, Kediri City in August $2020(\mathrm{n}=50)$.

\begin{tabular}{ccc}
\hline Self-Concept & f & \% \\
\hline Low & 27 & 54,0 \\
\hline High & 23 & 46,0 \\
\hline Jumlah & 50 & 100,0 \\
\hline
\end{tabular}

In the table, it can be seen that the majority of respondents have a disability level 1 of 35 people $(70.0 \%)$, with a stigma in the moderate category of 36 people $(72.0 \%)$ and a low self-concept of 27 people $(54.0 \%)$.

\section{Test Result of Bivariate Analysis}

Before carrying out the Multivariate Analysis Test, first a Correlational Test between variables was carried out with the following results: 


\section{STRADA Jurnal Ilmiah Kesehatan}

DOI: $10.30994 /$ sjik.v9i2.410

ISSN: 2252-3847 (print); 2614-350X (online)

Vol.9 No.2 November 2020 Page.926-935

Table 4 Bivariate Analysis between Levels of Disability and Self-Concept in Leprosy

Patients at Daha Husada Hospital, Kediri City in August $2020(\mathrm{n}=50)$.

\begin{tabular}{rlrr}
\hline & & Disability & \multicolumn{1}{c}{ Self Concept } \\
\hline Spearman's rho Disability & Correlation & 1.000 & $.374^{* *}$ \\
& Coefficient & & .007 \\
& Sig. (2-tailed) & 50 & 50 \\
& $\mathrm{~N}$ & & 1.000 \\
\cline { 2 - 3 } Self-concept & Correlation & $.374^{* *}$ & 50 \\
& Coefficient & .007 & \\
& Sig. (2-tailed) & 50 & \\
& $\mathrm{~N}$ & & \\
\hline
\end{tabular}

Table 5 Bivariate Analysis between Stigma and Self-Concept in Leprosy Patients at Daha Husada Hospital, Kediri City in August $2020(\mathrm{n}=50)$.

\begin{tabular}{llrrr}
\hline & & Disability & \multicolumn{1}{r}{ Stigma } \\
\hline Pearson & Disability & Correlation & 1.000 & $.340^{* *}$ \\
Correlation & & Coefficient & & .016 \\
& & Sig. (2-tailed) & 50 & 50 \\
& N & & 1.000 \\
& Stigma & Correlation & $.340^{* *}$ & \\
& & Coefficient & .016 & 50 \\
& Sig. (2-tailed) & 50 & \\
& $\mathrm{~N}$ & & \\
& & &
\end{tabular}

Based on the results of the Bivariate analysis, the results show that (1) there is a relationship between Level of Disability and Self-Concept; (2) there is a relationship between Level of Disability and Stigma; (3) there is a relationship between Stigma and Self-Concept.

\section{Multivariate Analysis Test Results}

After that, the Multivariate Test process was carried out which began with screening, as for the following results

Table 6 Examination Results of Variables Before Multivariate Analysis Variables in the Equation

\begin{tabular}{llrrrrrr}
\hline & & \multicolumn{1}{c}{ B } & \multicolumn{1}{c}{ S.E } & Wald & df & \multicolumn{1}{c}{ Sig. } & \multicolumn{1}{c}{ Exp (B) } \\
\hline Step 1 & Disability & -1.715 & .698 & 6.033 & 1 & 0.14 & -5.557 \\
& Constant & 2.193 & .873 & 6.302 & 1 & 0.12 & .112 \\
\hline Step 1 & Stigma & -1.842 & .788 & 5.465 & 1 & 0.19 & -6.309 \\
& Constant & 5.441 & 2.307 & 5.562 & 1 & 0.18 & .004 \\
\hline
\end{tabular}

Based on the table, the two independent variables, namely the level of disability and stigma, all have a $\mathrm{p}$ value $<0.25$ so that they can be used in further processing. The results of multivariate processing to analyze the Effect of Disability and Stigma Levels on SelfConcept in Leprosy Patients at Daha Husada Hospital, Kediri City using Logistic Regression Analysis, are as follows 


\section{STRADA Jurnal Ilmiah Kesehatan}

DOI: $10.30994 /$ sjik.v9i2.410

ISSN: 2252-3847 (print); 2614-350X (online)

Vol.9 No.2 November 2020 Page.926-935

Table 7 The Effect of Disability and Stigma Levels on Self-Concept in Leprosy Patients at Daha Husada Hospital, Kediri City in August $2020(n=50)$.

\begin{tabular}{|c|c|c|c|c|c|c|c|}
\hline \multicolumn{8}{|c|}{ Variables in the Equation } \\
\hline & & B & S.E & Wald & $\mathrm{df}$ & Sig. & $\operatorname{Exp}(\mathrm{B})$ \\
\hline \multirow[t]{3}{*}{ Step 1} & Disability & -1.732 & .845 & 4.204 & 1 & 0.40 & -5.652 \\
\hline & Stigma & -1.825 & .926 & 3.883 & 1 & 0.49 & -6.205 \\
\hline & Constant & 7.436 & 3.093 & 5.781 & 1 & 0.16 & .001 \\
\hline
\end{tabular}

Based on the table, it can be concluded that the level of disability and stigma affects the self-concept of leprosy patients at Daha Husada Hospital, Kediri.

\section{DISCUSSION}

\section{Disabilities in Leprosy Patients}

Based on the results of the study, it shows that leprosy patients are at a disability level of 0,1 and 2 with the majority being a disability level 1 of 35 people (70.0\%). This measurement of disability was carried out with nurses and physiotherapists who assessed patients during control based on the criteria of the Ministry of Health of the Republic of Indonesia. Leprosy defects in this study occurred due to impaired nerve function in the eyes, hands, or feet which indicated that the respondent had disabilities in all three parts, although at least the eyes were and some of the respondents had leg disabilities as indicated by complaints of difficulty walking, tread on the floor and sometimes feels tingling.

Level 0 disability is indicated by the absence of any abnormalities in the eyes, hands or feet due to leprosy. Grade 1 disability is a defect caused by invisible sensory nerve damage, such as loss of touch to the corneas, palms, and soles of the feet. Sensory dysfunction in the eye is not examined in the field, because there are no eye defects at defect level 1. Whereas the palms of the hands and feet are at risk of developing plantar ulcers, but with routine self-care this can be prevented. Meanwhile, level 2 disability means visible defects or damage, to the eyes, hands and feet. The general level of disability is determined based on the highest degree of defect in the eyes, hands or feet. Disability can result in deformity in the form of paralysis of the muscles (limbs or finger contractures) and / or tissue loss (atrophy) or partial reabsorption of the fingers.

The process of leprosy defects depends on the function and nerves on which part is damaged. Disability caused by leprosy can occur through 2 processes, namely (1) direct infiltration of M. Leprae into the peripheral nervous system and organs (for example the eyes); and (2) through the leprosy reaction. The leprosy reaction is interruption with an acute episode on a very chronic course. Leprosy reactions are hypersensitivity reactions, namely cellular hypersensitivity (type 1 reaction / reversal reaction), when there is an increase in cellular mediated immunity (CMI) or humoral hypersensitivity (type 2 reaction / erythema nodosum leprosum). Leprosy reactions can occur before treatment, but mainly occur during or after treatment. The exact cause of the reaction is not clear. It is estimated that a number of triggering factors play an important role. The reactions are divided into 2 types, are described as follows

1. Type 1 reaction

This reaction is more prevalent in patients with different borderline spectrum (borderline lepromatos, borderline-borderline and borderline tuberculoid), because this borderline type is an unstable type. This type of reaction results in an inflammatory response in the affected area of the skin and nerves. Inflammation of the nerve tissue can result in damage and disability. Symptoms of a type 1 reaction can be seen in the 


\section{STRADA Jurnal Ilmiah Kesehatan}

DOI: $10.30994 /$ sjik.v9i2.410

ISSN: 2252-3847 (print); 2614-350X (online)

Vol.9 No.2 November 2020 Page.926-935

form of changes in the skin, as well as nerves in the form of inflammation. In general, the form of part or all of the existing lesions becomes active and or new lesions appear in a relatively short time; meaning that the hypopigmented lesion becomes erythema, the erythema lesion becomes more erythematous, the macular lesion / spots become infiltrates / plaques, the plaque lesions become more infitative and the old lesions become more extensive.

2. Type 2 reaction

Occurs in patients with type MB (lepromatous leprasy and borderline lepromatous). It is a humoral reaction in the form of an antigen (M. leprae) reaction and the patient's antibody will activate the complement system to form an immune complex. This immune complex will cause an inflammatory response and will be degraded within a few days. Because it circulates in the blood circulation, this immune complex can deposit to various organs, especially at locations where $M$. leprae is in high concentrations: such as the skin (ENL), nerves (neuritis), lymph nodes (lymphadenitis), bones (arthritis), kidneys (nephritis), and testes (orchitis). The clinical symptoms on the skin are nodes, erythema, and pain with predilection sites in the arms and legs. These symptoms generally disappear within a few days or more and may be followed by the formation of new nodes while the old nodes turn purple. The course of the reaction may last 3 weeks or more.

In general, there are 3 types of nerve function, namely motor function to provide strength to muscles, sensory function to provide sensation of touch, pain and temperature and autonomic function to manage sweat glands and oil glands. The disability that occurs depends on the affected nerve component, can be sensory, motor, autonomic, or a combination of the three.

According to pathogenesis, the nervous system affected by this disease is the peripheral nervous system, especially some nerves, such as the facial, radial, ulnar, median, popliteal (peroneus communis) and posterior tibial nerves. Impairment of sensory, motor and autonomic function of these nerves in particular pay attention to the characteristic picture of disability. Abnormalities arising from impaired nerve function include (1) Facialis nerve: the eyelids feel heavy closing; (2) Ulnar and median: the ring and little fingers are bent and some respondents experience numbness in the palms around the thumbs and the index fingers appear weak; (3) Radialis: some respondents experience limp hands and (4) Peroneus: feet are unable to tread and (5) posterior tibia: numbness in the soles of the feet. Disability is a broad term whose meaning includes any damage, limitation of activities that affect a person. Each new patient found should be noted for the level of disability. Each organ (eyes, hands, and feet) is assigned its own level of defect. The highest disability rate is the defect rate for that patient (general disability rate).

The level of disability of a patient will affect his self-concept indicated by $\mathrm{p}$ value $=$ 0.007 and $r=0.384$. Leprosy patients experience impaired self-concept, especially in the body image component. The higher the level of disability will increase 5,652 times the potential for self-concept change.

\section{Stigma in Leprosy Patients}

Based on the results of the study, it was found that the stigma was moderate as many as 36 people (72\%). The dimensions of Stigma that are measured in respondents are (1) alienation, (2) stereotype support, (3) discrimination, (4) social withdrawal and (5) stigma resistance. $^{8}$ 


\section{STRADA Jurnal Ilmiah Kesehatan}

DOI: $10.30994 /$ sjik.v9i2.410

ISSN: 2252-3847 (print); 2614-350X (online)

Vol.9 No.2 November 2020 Page.926-935

Alienation or alienation comes from the English word "alienation" and the Latin word "alienato" which means to alienate something or a situation. The Cambridge Dictionary of psychology explains that in existential psychology the term alienation is used to describe a person's feelings that are separated from experience, so that the experience seems alien to him, even like a drama or television show of something real. In addition, in social psychology, "alienation" is often used to describe a situation in which a person feels alien from himself and turns away from his surroundings so as to encourage that person to be hostile towards other people or society. Thus human alienation is a mental disorder in which a person loses control of himself so that it has the potential to cause destructive effects on himself and his surroundings. Stereotype is a frame of mind or cognitive aspect consisting of knowledge and beliefs about certain social groups and certain traits. According to Rahman, stereotypes are beliefs about certain characteristics of certain group members. Stereotypes are cognitive components which are beliefs about personal attributes possessed by people in a particular group or social category. Discrimination is behavior that puts others down because of their membership in a group. ${ }^{9}$ Discrimination is a behavioral component which is negative behavior towards individuals because the individual is a member of a certain group. Social withdrawal is a disorder of feelings and thoughts. Shy temperament may appear similar but without significant peer disturbance, language and speech disorders or early traumatic experiences and certain illnesses that can lead to social isolation with close family members or the surrounding environment. Stigma resistance is a new and promising concept. The development of beliefs that defy stigma can assist individuals in their hope of finding fulfilling lives and in their recovery from mental illness. ${ }^{8}$

The stigma mechanism is divided into four, namely ${ }^{10}$ :

1. There is direct negative treatment and discrimination

The first mechanism of stigma is negative treatment and direct discrimination, which means that there are restrictions on access to life and direct discrimination that have an impact on social status, psychological well-being and physical health. Stigma can occur in several places, such as in a shop, workplace, educational settings, health services and the criminal justice system.

2. The process of confirming your hopes or self-filling prophecy

Stigma becomes a process through confirmation of expectations or (self-filling prophecy). Negative perceptions, stereotypes and expectations can lead individuals to behave in accordance with the given stigma so that it affects the thoughts, feelings and behavior of the individual.

3. The automatic emergence of stereotypes

Stigma can be a process through the automatic activation of negative stereotypes in a group.

4. The occurrence of a threat process to the identity of the individual.

The perception that people with leprosy are personally responsible for the disease they carry from large-scale publications about people who are at high risk of contracting leprosy. There are several consequences resulting from the development of stigma, namely $: 11$

1. Stigma makes it more difficult to restore life because stigma can lead to erosion of self-confidence and thus withdrawing from society. Due to the defects that arise as a result of this leprosy, a lot of leprosy patients withdraw from the environment. 


\section{STRADA Jurnal Ilmiah Kesehatan}

DOI: $10.30994 /$ sjik.v9i2.410

ISSN: 2252-3847 (print); 2614-350X (online)

Vol.9 No.2 November 2020 Page.926-935

2. Stigma causes discrimination, making it difficult to find accommodation and work. Due to the clinical manifestations that arise and the complications that occur. People also feel reluctant to live side by side with leprosy patients.

3. Physical disability. Due to the complications obtained from leprosy patients, society becomes less human. Maybe people are afraid this disease can spread to them. Even if they had sufficient knowledge about leprosy, their attitude or behavior towards leprosy patients could not have been like this. Her family became even more humiliated and disturbed. Because their family members have leprosy, the family is also ostracized by the community.

4. Society is harsher and less humane

Why is that, because of the complications obtained from leprosy patients, society becomes less human. Maybe people are afraid this disease can spread to them. Even if they have sufficient knowledge about leprosy, their attitude or behavior towards leprosy patients might not be like this.

5. Her family became even more humiliated and disturbed

Because their family members have leprosy, the family is also ostracized by the community.

Label at risk in leprosy patient can have a negative impact on the population. Labeling leprosy sufferers as a risk group in the community due to the disability condition caused by the disease. This will have an impact on leprosy clients who will place leprosy clients as members of the minority community socially due to people's fear of leprosy transmission. The population condition of leprosy as a population at risk has resulted in inadequate health services received by this group. The leprosy population is stigmatized and badly labeled because of the physical condition of leprosy, such as wounds on the skin which are horrible and very dirty. Leprosy is generally suffered by a group of low socio-economic class conditions, the existence of this condition results in inadequate handling so that it will be very infectious to the surrounding community.

The social impact of leprosy causes problems of social isolation and social discrimination for lepers in the community. Acceptance of leprosy in the community is still difficult, this is because leprosy is a contagious, incurable disease, hereditary disease, a curse, and causes disability. This has resulted in leprosy sufferers feeling hopeless so that they do not persistently seek treatment. This can be proven by the fact that disease has a special position among other diseases, so that there is a tendency that the leprosy problem has shifted from a health problem to a social problem.

The social problems of leprosy will result in clients of leprosy in the community experiencing a grieving process. Losing a role will experience a grieving process. Loss is an actual and potential situation when something valuable must go away or disappear and do not return from the client's life. Leprosy clients who are declared leprosy will feel they have lost something, for example their health so far because they will feel that they are now sick. The sick condition experienced by leprosy clients will develop in the emergence of grieving reactions in their lives. Grieving is an emotional reaction to loss and usually occurs as a result of separation which is manifested in behavior, feelings and thoughts (eg Crying, gloom and withdrawal). Individuals who experience grief try various strategies to deal with it, individuals will carry out four tasks of grief, namely accepting the reality of life from loss, experiencing the pain of loss, adjusting the environment, and re-energizing emotional energy into new relationships. Clients diagnosed with leprosy will try various strategies to deal with the crisis they are experiencing so that they will go through their grieving reactions naturally. 


\section{STRADA Jurnal Ilmiah Kesehatan}

DOI: $10.30994 /$ sjik.v9i2.410

ISSN: 2252-3847 (print); 2614-350X (online)

Vol.9 No.2 November 2020 Page.926-935

Stigma will result in a social discrimination that causes an impact of fear on individuals and families to seek help for what they need. ${ }^{12}$

\section{Self Concept in Leprosy Patients}

Based on the research results, it was found that the low self-concept was 27 people (54\%). According to Yusuf a positive self-concept gives a person a sense of meaning, holiness, and consistency. ${ }^{13}$ A healthy self-concept has a high degree of stability and results in positive feelings about oneself. The components of self-concept that are often considered by nurses are identity, body image, and role appearance. The range of selfconcept responses according to Stuart and Sudden in Shuron is (1) Self-actualization, namely self-questions about positive self-concepts with a background of experience that is real success and acceptance. (2) Positive Self-Concept, when individuals have positive experiences in self-actualization. (3) Low Self-Esteem is a transition between an adaptive self-concept response and a maladative self-concept response. (4) Identity disorder is the failure of individuals to integrate aspects of childhood identity into the maturity of the psychosocial aspects of personality in harmonious adulthood. ${ }^{14}$

According to Tarwoto, self-concept is influenced by several factors as follows: (1) Level of development and maturity. (2) Culture. (3) External and internal sources, strength and development in individuals greatly influence self-concept. In internal sources, such as humorous people, individual coping is more effective. External sources, such as support from the community and a strong economy. (4) The experience of success and failure, there is a tendency that a history of success will improve self-concept and vice versa. (5) Stressors in life, such as marriage, new job, tests, and fear. If the individual's coping is inadequate, it will lead to depression, withdrawal, and anxiety. (6) Age, illness, and trauma, old age and illness will affect their self-perception. ${ }^{15}$

Individuals from birth and begin to grow know themselves first by getting to know other people. When we were little, the important people around us were parents and siblings. How other people know us to form our self-concept, self-concept can be formed due to various factors, both external and internal. The factors become even more specific and will be closely related to the self-concept that will be developed by the individual. ${ }^{16}$

\section{Analysis of Disability and Stigma On Self-concept}

Based on the research results, it was found that the low self-concept was 27 people (54\%). According to Yusuf (2015) a positive self-concept gives a person a sense of meaning, holiness, and consistency. A healthy self-concept has a high degree of stability and results in positive feelings about oneself. The components of self-concept that are often considered by nurses are identity, body image, and role appearance. The range of self-concept responses according to Stuart and Sudden in Shuron is (1) Self-actualization, namely self-questions about positive self-concepts with a background of experience that is real success and acceptance. (2) Positive Self-Concept, when individuals have positive experiences in self-actualization. (3) Low Self-Esteem is a transition between an adaptive self-concept response and a maladative self-concept response. (4) Identity disorder is the failure of individuals to integrate aspects of childhood identity into the maturity of the psychosocial aspects of personality in harmonious adulthood. ${ }^{14}$

According to Tarwoto, self-concept is influenced by several factors as follows: (1) Level of development and maturity. (2) Culture. (3) External and internal sources, strength and development in individuals greatly influence self-concept. In internal sources, such as humorous people, individual coping is more effective. External sources, such as support 


\section{STRADA Jurnal Ilmiah Kesehatan}

DOI: $10.30994 /$ sjik.v9i2.410

ISSN: 2252-3847 (print); 2614-350X (online)

Vol.9 No.2 November 2020 Page.926-935

from the community and a strong economy. (4) The experience of success and failure, there is a tendency that a history of success will improve self-concept and vice versa. (5) Stressors in life, such as marriage, new job, tests, and fear. If the individual's coping is inadequate, it will lead to depression, withdrawal, and anxiety. (6) Age, illness, and trauma, old age and illness will affect their self-perception ${ }^{15}$

Individuals from birth and begin to grow know themselves first by getting to know other people. When we were little, the important people around us were parents and siblings. How other people know us to form our self-concept, self-concept can be formed due to various factors, both external and internal. The factors become even more specific and will be closely related to the self-concept that will be developed by the individual.

\section{ACKNOWLEDGMENTS}

We thank the Ministry of Science Research, Technology and Higher Education of Indonesia (RISTEKDIKTI RI) for Research Grants 2019 and providing 2020. We thank you to Director of Kediri Daha Husada Hospital and all research respondents

\section{REFERENCES}

1. Kunouli. Asuhan Keperawatan Penyakit Tropis. Jakarta: CV Trans Info Media; 2012.

2. Srinalesti Mahanani DNTI. Buku ajar keperawatan paliatif : asuhan keperawatan pasien kusta berfokus pada aspek psikologi dan sosial. Kediri: CV. Adjie Media Nusantara; 2020.

3. Sipahoetar VR. Dukungan Sosial Keluarga dan Pencegahan Kecacatan Pada Pasien Kusta. STIKES RS Baptis Kediri; 2019.

4. Indonesia KR. Pedoman Nasional Progam Pengendalian Penyakit Kusta. Jakarta: Bakti Husada; 2012.

5. Nsagha, D.S., Bissek, A. C. Z., Njuanda AL. Social Stigma as an Epidemological Determinant for Leprosy Elimination in Cameroon. J Public Health Africa. 2018;2.

6. Dhelya W. Penyakit Kusta Sebuah Prespektif Klinis. Malang: UB Press; 2018.

7. Wiwiek N. Gambaran Konsep Diri Klien Kusta. J Ilm Kesehat. 2013;5(2).

8. (ILEP) IF of A-LA. Giudelines To Reduce Stigma : How To Assess Health-related Stigma. King College London; 2011.

9. Rahman. Hubungan pengetahuan dan sikap masyarakat terkait kusta terhadap perlakuan diskriminasi pada pasien kusta. Med Respati. 2013;11(3).

10. Taylor, A., Peplau, T., Sears W. The Quality off Life, Mental Health and perceived Stigma of Leprosy Patients in Bangladesh. Soc Sci Med. 2009;64(12):2443-53.

11. Dkk S. Faktor-Faktor yang melatarbelakangi persepsi penderita terhadap Stigma penyakit Kusta. J Promosi Kesehat Indones [Internet]. 2009;4(1). Available from: https://ejournal.undip.ac.id/index.php/jpki/article/view/2409

12. Susanto. Perawatan Klien Kusta Di Komunitas. Jakarta: Trans Info Media; 2013.

13. Yusuf A. Buku Ajar Keperawatan Kesehatan Jiwa. Jakarta: Salemba Medika; 2015.

14. Suhron M. Asuhan Keperawatan Jiwa Konsep Self Esteem. Jakarta: Mitra Wacana Media; 2017.

15. Tarwoto. Kebutuhan Dasar Manusia dan Proses Keperawatan. Jakarta: Salemba Medika; 2010.

16. Sari. Analisis Faktor Yang Berhubungan Dengan Harga Diri Pasien Kusta Di RS. Kusta Kediri. Stikes RS. Baptis Kediri; 2017. 